\title{
O PROFETA AMERICANO: A INFLUÊNCIA DO PROFÉTICO EM MARTIN LUTHER KING JR
}

\author{
THE AMERICAN PROPHET: \\ THE INFLUENCE OF THE PROPHETIC ON MARTIN LUTHER KING JR ${ }^{1}$
}

\author{
David T. Ritchie*
}

RESUMO: A fundamentação dos direitos civis americanos no pensamento pioneiro de Martin Luther King Jr. é tão variada e diversa quanto sua visão para um nova sociedade americana. Obviamente que pelo fato de Luther King ter sido pastor da igreja batista, suas reflexões foram formatadas pelos princípios da fé cristã. Entretanto, também foi influenciado por ideais religiosos e seculares de outras tradições. Neste artigo, pretendo discutir a influência do pensamento do teólogo judaico e filósofo social Martin Buber na filosofia de Luther King. Em particular, examinarei como o conceito buberiano do "outro" foi incorporado em sua teoria sobre transformação social e não-violência. Tal influência, reconhecida pelo próprio Luther King, raramente é discutida como um dos fundamentos de seu pensamento filosófico maduro. Consequentemente, uma análise dessa conexão é vital para a compreensão da gênese e importância do pensamento de Luther King.

PALAVRAS-CHAVE: Martin Luther King Jr. Martin Buber. Direitos Civis. O “Outro”. Não-violência

ABSTRACT: The foundations of U.S. civil rights pioneer Martin Luther King Jr.'s thought are as varied and diverse as his vision for a new American society. As a Baptist minister his ideas were of course shaped by the Christian ideals of that faith. He was also influenced, however, by religious and secular ideals from other traditions. In this article I discuss the effect of the work of the Jewish theologian and social philosopher Martin Buber on King's philosophy. In particular, I examine how Buber's notion of "the other" crept into King's theories on social change and nonviolent action. This influence, while noted by King himself, is not often discussed in the context of where King's mature philosophical vision came from. Consequently, an examination of this connection is vital to understanding both the genesis and importance of King's thought.

KEYWORDS: Martin Luther King, Jr. Martin Buber. Civil Rights. The other. Nonviolence

* Associate Professor of Law, Mercer University School of Law, Macon, Georgia. B.A. (Cleveland State University); J.D. (Howard University School of Law); LL.M. (Temple University School of Law); Ph.D. (University of Oregon).

1 The idea for this paper was derived from a project I did for a class on Martin Buber and Emmanuel Levinas at the University of Oregon. I would like to thank the members of that class for their feedback, as well as my friend and mentor Cheyney Ryan. Cheyney's readings of the texts of Buber and Levinas are embedded deeply within my interpretations. For that, and so many other things, I owe him an unending debt of gratitude. Also, I would like to thank Ana Leticia Barauna Duarte Medeiros for her constant patience and sage counsel. I benefit from her advice more than she knows. My colleagues Tim Floyd, Mark Jones, and Jack Sammons also deserve thanks for their fellowship and their assistance with this essay. Finally, thanks go to the Dean Daisy Hurst Floyd at the Mercer University School of Law who has always supported my scholarly endeavors, and to my research assistant Brian Jasper for his excellent assistance with this project. 
The eschatological, as the "beyond" of history, draws beings out of the jurisdiction of history and the future; it arouses them in and calls them forth to their full responsibility. ${ }^{2}$

\section{INTRODUCTION}

The influence of the work of Martin Buber on Martin Luther King, Jr.'s intellectual development has been frequently noted, by King himself and his biographers. ${ }^{3}$ Aside from these annotations, however, the impact of the philosophical viewpoints developed by Buber and others in the prophetic tradition upon the thought of King has not been explored in any depth. It is my belief that the mature philosophical views of Martin Luther King, Jr. are intimately related to what I will call the "prophetic inclination."4 Indeed, I would argue further that one can only fully understand the true nature of King's vision if they appreciate the connections between his work and the philosophical foundations of work by other prophetic theorists like Martin Buber and Emmanuel Levinas. What I intend to show, then, is the many similarities between King's intellectual commitments and those held by individuals coming from the prophetic tradition. This path will open up, I believe, a fresh insight into the radical nature of King's social and political thought, and may serve to connect his work to a philosophical inclination which is historically extant if traditionally unappreciated in academic circles.

\section{MARTIN LUTHER KING, JR. AND HIS SOCIAL AND POLITICAL PHILOSOPHY}

Martin Luther King, Jr. was born in 1929 in Atlanta, Georgia to a Baptist preacher and his wife, in a time when African Americans were officially second class citizens in

2 Emmanuel Levinas, Totality and Infinity: An Essay on Exteriority (Pittsburgh, Pa: Duquesne University Press, 1961), p. 23.

3 King cites the importance of Buber's work in his dissertation, a critical comparison of the thought of Paul Tillich and Henry Nelson Wieman, submitted for the Ph.D. degree at Boston University in 1955. See, Martin Luther King Jr., The Collected Papers of Martin Luther King, Jr.: Vol. II (Berkeley: University of California Press, 1994). He also explicitly relies on Buber's views in his "Letter from a Birmingham City Jail." This connection has also been frequently noted by King's biographers and commentators on his work. See, e.g., Lewis V. Baldwin, There is a Balm in Gilead: The Cultural Roots of Martin Luther King, Jr. (Minneapolis, Minn.: Augsburg Fortress, 1991), p. 290; James A. Colaiaco, Martin Luther King, Jr.: Apostle of Militant Nonviolence (London: MacMillan Press, 1988), pp. 87-88; and Hanes Walton, Jr., The Political Philosophy of Martin Luther King, Jr. (Westport, Conn.: Greenwood Publishing Co., 1971), pp 44-45.

4 Certainly the choice of this term waves in the direction of Martin Buber's influential work, The Prophetic Faith. See, Martin Buber, The Prophetic Faith (New York: Collier Books, 1985). In this book, Buber engages in Biblical exegesis in an attempt to show how the stories about the Jewish prophets compel us to accept a certain ethical vision about the interaction between individuals. There has also been other fascinating work in this regard, particularly by Walter Brueggemann. See, Walter Brueggmann, The Prophetic Imagination (Minneapolis, Minn.: Fortress Press, 2001). My colleague Tim Floyd has also used this notion in some of his work. See, for example, Timothy W. Floyd, "Lawyers and Prophetic Justice," Mercer Law Review, Vol. 58 (2007), pp. 513-30. 
the United States. As a young man, King studied theology at the Crozer Theological Seminary in Chester, Pennsylvania where he was undoubtedly introduced to the works of major theorists of other religious traditions, including Judaism. After earning his divinity degree ${ }^{5}$ from Crozer, King went on to study philosophy and systematic theology at Boston University, where he was introduced to the works of notable European social and religious thinkers. It was during this time that King began his lifelong dedication to ecumenical understanding. King's Ph.D. thesis was an examination of conceptions of God in the works of the German theologian Paul Tillich and the American protestant theorist Henry Nelson Wieman. ${ }^{6}$

Even before he finished his doctoral studies, King had embarked upon a career dedicated to fighting the oppression of Blacks in the U.S. At the age of 25 King became the pastor of the Dexter Avenue Baptist Church ${ }^{7}$ in Montgomery, Alabama, the heart of the growing civil rights movement in the American south. ${ }^{8}$ From this time until his death in 1968 King was a nationally recognized leader in the U.S. civil rights movement. ${ }^{9}$ King's leadership was instrumental in protests and organized civil rights activities inamong other places-Albany, Georgia and Birmingham, Alabama. It was around this time that King was introduced to the philosophy ${ }^{10}$ of satyagraha, the theory of nonviolent social resistance developed by Mohandas K. Gandhi and implemented in his struggles against racism in South Africa and colonialism in India. ${ }^{11}$ King was a prominent member of the Congress of Racial Equality (CORE), and was the first leader of the Southern

5 A degree in divinity is the basic undergraduate degree (bachelor's degree) for those who wish to enter protestant ministry.

6 Wieman himself was a student of the Harvard social and political philosopher Ralph Barton Perry.

7 King would also serve as a minister at the Ebenezer Baptist Church in Atlanta, Georgia, the present site of the Martin Luther King, Jr. National Historic Site http://www.nps.gov/malu/index.htm and the King Center http://www.thekingcenter.org,.

8 Montgomery, Alabama is the site of the now famous bus boycott, where Rosa Parks (a Black woman) was arrested for refusing to relinquish her seat to a white rider and move to the back of the bus. The Dexter Avenue Baptist Church was the gathering point for protestors during the boycott, and King was a prominent leader in this movement.

9 King's influence reached to the highest levels of government. He had direct communications with the White House during both the Kennedy and Johnson administrations. He was also recognized internationally for his social activism. In 1964 he was awarded the Nobel Peace Prize for his work on desegregation in the United States, thus validating the effectiveness of his social and political commitments.

${ }^{10}$ King was introduced to Gandhi's works by the American activist Bayard Rustin. See, Scott H. Bennett, Radical Pacifism: The War Resisters League and Gandhian Nonviolence in America, 1915-1963. (Syracuse, N.Y.: Syracuse University Press, 2003), pp. 217. King later went to India to meet with the family and friends of Gandhi. Martin Luther King, Jr., et al., The papers of Martin Luther King, Jr., (Berkeley, Calif.: University of California Press, 1992), pp. 3, 135-36.

${ }^{11}$ For representative selections on Gandhi's writings on nonviolence see, M.K. Gandhi, Gandhi on Nonviolence: A Selection from the Writings of Mahatma Gandhi (New York: New Directions Press, 1965). 
Christian Leadership Conference (SCLC). ${ }^{12}$ He largely organized the activities of all the major civil rights campaigns in the American south from 1954 to his death at the hands of an assassin in 1968. Throughout these activities, King maintained a strict adherence to the theory of Gandhian nonviolence, and consistently espoused the view that the best way to achieve the goals of the movement for racial equality was to earn the respect of those who opposed him. ${ }^{13}$

For Martin Luther King, Jr., the struggle for racial equality in the United States was not just about overcoming the oppression that African Americans faced (especially in the south). To King, racism and the effects of official segregation were as injurious to those who opposed racial integration and fought against granting Blacks full legal equality as it was to the victims of such policies. According to King, the degradation of racism cuts both ways: it harms the oppressed by its direct social and personal effects, but it also harms the oppressor by rotting away at their moral core. ${ }^{14}$ Because of this relationship between oppressor and oppressed, King believed that the only way out of the dilemma of racism and bigotry was to cross the divide and succeed in having the Other see you as human and worthy of recognition. To do this, you must grant the Other the same respect. This was a difficult and dangerous gamble to take in the face of the violent and radical white supremacists that populated both overtly racist organizations like the $\mathrm{Ku}$ Klux Klan (KKK) and public institutions such as state and municipal governments (particularly police departments) infused with white bigots. It should be said that this stance also became a source of criticism against King by other anti-segregation leaders such as Malcolm X, who argued that only outright physical violence on the part of the oppressed black masses could end the legacy of racism and change the dynamic of oppression between blacks and whites in the U.S.

According to King, however, the path to a better future was not a war between the races, but the development of a "beloved community" wherein people with different (sometimes radically different) backgrounds, perspectives, and investments (philosophical and otherwise) could peacefully co-exist. King's commitments to ministering, to full social, political and legal equality, to nonviolent action, and to the recognition of the Other in the face of often violent opposition form the core of his beloved community. From his earliest academic work, to his later social and political activism, Dr. King exemplified

${ }^{12}$ See, David Garrow, Bearing the Cross: Martin Luther King, Jr. and the Southern Christian Leadership Conference (New York: Harper, 2004).

${ }^{13}$ Martin Luther King, Jr., et al., The papers of Martin Luther King, Jr., (Berkeley, Calif.: University of California Press, 1992), pp. 135-36.

14 This particular strain in King's thought was undoubtedly related to his study of "personalism" under Edgar Brightman at Boston University. See, e.g., Warren Steinkraus, Studies in Personalism: Edgar Sheffield Brightman (Meridian, Miss.: Meridian Pub., 1984). 
the principles that he wished he could (and one day might) see in a new and more just American society. These views had a number of influences, of course. Among them were certainly the nonviolence of Gandhi, the personalism of Brightman, and the vision of divinity attributed to Tillich. I believe, though, that the linchpin of all this, the sine qua non to King's entire philosophical system, was the recognition and humanization of the Other that he derived from Buber's thought.

\section{THE PROPHETIC INCLINATION}

There is a strain in continental European philosophy which attempts to revision epistemology and fundamental ontology to escape the Cartesian dualism that has dominated Western thought for centuries. This line begins with Jewish theologians of the $19^{\text {th }}$ century such as Franz Rosenzweig, and continues right the way through the Frankfurt School, and up to people like Georges Bataille, Emmanuel Levinas, Michel Foucault and Jacques Derrida. Deeply embedded in this tradition is the thought of Martin Buber, a Jewish philosopher who tried to wrest the minds of those of us in the Western philosophical tradition away from purely instrumental modes of thought to a vision of ethical and relational clarity. This tradition, which has played a central role in postmodern philosophy, attempts to give alternative and outsider voices an airing; to give traditionally underappreciated viewpoints legitimacy. It perhaps makes sense that this is derived from the Jewish experience.

The Western philosophical tradition, loosely defined, has been characterized as a move to assimilate and appropriate alternative viewpoints, to make the other same to use Levinasian language. The epistemological model at work in Western philosophy, according to this characterization, is one which necessitates a hierarchical matrix that relegates philosophical positions either above or below competing positions (usually determined by some fixed sense of truth or a preconceived conceptual reference point). This model is, in short, one which operates on a premise of domination and conquest. If a philosophical view does not prevail over another it loses, it is scavenged for whatever useful bits it might contain, and is thereafter relegated to the island of mis-fit concepts (indeed, this is the paradigm explicitly endorsed by American pragmatism ${ }^{15}$ ). What we might call western Philosophy, then, is a never-ending quest for objective truth and unfaltering autonomy for those who serve as the progenitors or repositories of such "truths."

An alternative to this epistemology of subjugation and incorporation has been developed by individuals who work in what has been called the prophetic tradition. This

15 American pragmatism is usually most closely associated with William James, Charles Sanders Peirce, and William James. Later, people like Hillary Putnam, W.O. Quine, and Richard Rorty were associated with this movement. For an interesting discussion on American pragmatism, see Cornel West, The American Evasion of Philosophy: A Genealogy of Pragmatism (Madison, Wisc.: University of Wisconsin Press, 1989). 
alternative tradition seeks to illuminate voices which have been squelched and banished to that island of mis-fit concepts, to provide room for a discourse of the Other. In effect, the prophetic tradition fosters and treasures alterity and heteronomy. The perspective of the Other takes precedence compared to that of one's self (or tradition). Here the inclination is one of hospitality and respect rather than domination and assimilation. The foreign, the Other, the different is acknowledged on its own terms.

The views of the Other cannot be appropriated, but must be faced with consideration and addressed directly. We should not take this too far, however. We must be careful not to be Pollyanna about the implications of the prophetic viewpoint. I am not attempting to illuminate a sort of watered down relativism and intellectual collegiality which places extreme importance on a banal form of sterile grey conceptualism that refuses to positively advocate for anything save for the premise from which it starts. Instead, the very real possibility of conflict with the Other must be acknowledged. In fact, it is this possibility-perhaps inevitability-that marks the true move to hospitality and acceptance. Accepting one who you agree with, the Other like you, is easy; accepting and respecting the Other who is foreign, different, strange requires an act of will.

It is important to recognize that the prophetic inclination does, at some level, seek to have an effect upon the Other, and does not insist that one must stand by and watch as the Other abuses the move toward hospitality to its advantage. Indeed, advocates of the prophetic inclination do not naively believe that their perspective will be universally embraced without some sort of struggle. It is the locus of this struggle and the terms of its engagement, however, which sets the prophetic viewpoint apart. Whereas the traditional epistemological model of Western philosophy aims the struggle for ascendency outward upon one's opponent, the prophetic inclination aims this struggle inward. One's self or philosophical position is to be made vulnerable to the Other, opened up if you will, so that the Other might examine and reflect upon it in its entirety and exteriority. In short, the struggle is ethical in nature. This is why Levinas privileges ethics as first (or foundational) philosophy.

The mechanisms employed during this struggle are markedly different in the prophetic inclination. Instead of appropriation and domination-mechanisms of violence and control-the prophetic tradition places an emphasis on showing hospitality to the Other and embracing the obligations which such a move necessarily involves. The struggle is to see how your own view affects the Other and acknowledge the legitimacy of the Other's alterity. This imagery is one which accents the absence of violence, or to state it in a more positive manner, this inclination makes sacred the security of all things alternative from the violent mechanisms of domination and control mentioned above. Advocates of this view do not shun conflict, but rather seek to funnel conflict between competing positions into a journey of self-reflection and openness to the Other. 


\section{BUBER, LEVINAS AND THE PROPHETIC}

As I mentioned at the outset, the themes which I have been attributing to this prophetic inclination take shape most clearly in the thought of Martin Burber, and more recently in the work of Emmanuel Levinas. A closer examination of their articulations of this inclination should begin to illuminate the connections between this tradition and the later social and political philosophy of Martin Luther King, Jr. In particular, Buber is important here as his work was explicitly influential on the development of King's philosophical perspective. In his writings Buber spent a great deal of time discussing the relationship between individuals, ${ }^{16}$ laying out the terms of a dialogue which would circumvent the traditional move of appropriation and domination which he saw in Western thought. ${ }^{17}$ Buber hoped to develop an alternative model of dialogue which would vitiate the importance of the issue of power, and concentrate instead on the themes of redemption, transcendence and the absence of violence. At base, Buber firmly believed that the trend, in philosophy and in Western culture, was to treat interactions between individuals as merely functional or instrumental in nature. The growth of market capitalism and the expectation of return in personal relationships, based at least in part on the egoism developed by theorists in psychoanalytic circles, seemed to Buber to reduce our ability to see beyond the functional aspects of dialogue with others.

In I and Thou, ${ }^{18}$ his most well know work, Buber details the relationship between one's self and the Other which rises above this merely functional association of independent and autonomous individuals-which he characterizes as the "I - It" relationship. The more exceptional or laudatory association-which Buber calls the "I - Thou" relationship_is one which serves as the basis of true being. In effect, what it means for us to be beings is intimately related to our ability to engage in "I - Thou" relations, or to be more precise, our true being is played out in the course of such relations. Speaking of the emergence of this being, Buber says that

${ }^{16}$ Buber clearly believed that one could have a relationship with other entities besides other humans, but for the purposes of this paper I will exclusively concentrate on his discussion of the interactions between persons as this is most relevant to the social and political theme I wish to pursue.

${ }^{17}$ Franz Rosenzweig was a contemporary of Martin Buber who also developed a notion of the Other. See, Franz Rosenzweig, The Star of Redemption (Madison, Wisc.: University of Wisconsin Press, 2005). For Rosenzweig, transcendence is founded in the ethical relationship brought on by the "face to face" encounter with the other. For an interesting discussion of this, and a detailed analysis of the connections between the work of Rosenzweig and Emmanuel Levinas, see Bettina Bergo, Is There a "Correlation" Between Rosenzweig and Levinas? The Jewish Quarterly Review, Vol 96 (Summer 2006), pp. 404-12.

${ }^{18}$ Martin Buber, I and Thou (New York: Collier Books, 1958). 
In the beginning is relation-as category of being, readiness, grasping form, mould for the soul; it is the a priori of relation, the inborn Thou. The inborn Thou is realised in the lived relations with that which meets it. ${ }^{19}$ [emphasis in original]

While it will always be the case that we operate to some extent on the level of "I - It" relations, our true being only emerges insofar as we strive for and achieve "I - Thou" relations. This point is extremely important, as it takes the dialogical connection articulated by Buber beyond the realm of personal or social interaction (or relational psychology) and into the domain of epistemology or fundamental ontology; a fact explicitly recognized and developed by Emmanuel Levinas in his essay on "Martin Buber and the Theory of Knowledge. ${ }^{{ }^{20}}$ The primary implication to be drawn from the epistemological or ontological nature of Buber's paradigm is that the recognition of the interests of the Other and the acceptance of that Other in its alterity-the forging of an "I - Thou" relationship-gives one access to her own true being; such relationships allow one to raise up and, in a sense, redeem themselves (from their merely functional or instrumental existence as typified in "I - It" relations) in true being. ${ }^{21}$ According to Buber,

[r]elation is mutual. My Thou affects me, as I affect it. We are molded by out pupils and built up by our works. The "bad" mad, lightly touched by the holy primary word, becomes one who reveals. How we are educated by children and by animals! We live our lives inscrutably included within the streaming mutual life of the universe. ${ }^{22}$

Buber's most consistent, and perhaps most faithful, interpreter is the French philosopher Emmanuel Levinas. In his work, Levinas developed the conception of the Other as found in Buber's work. He says, for example, in Totality and Infinity, that " $[\mathrm{t}]$ he Other qua Other is situated in the dimension of height and of abasement-glorious abasement; he has the face of the poor, the stranger, the widow, and the orphan, and, at the same time, of the master called to invest and justify my freedom." ${ }^{23}$ This is an ethical relationship between one's self and the Other. In this relationship we see the Other in her alterity, but we also see ourselves. This is an ethical relationship, but it is-at base-phenomenological. ${ }^{24}$ Our lived experience is dependent upon acknowledging the Other.

One imagines that this "raising up" of a felt or lived ethical relationship would translate into an environment of dialogue which is substantively more just than that we

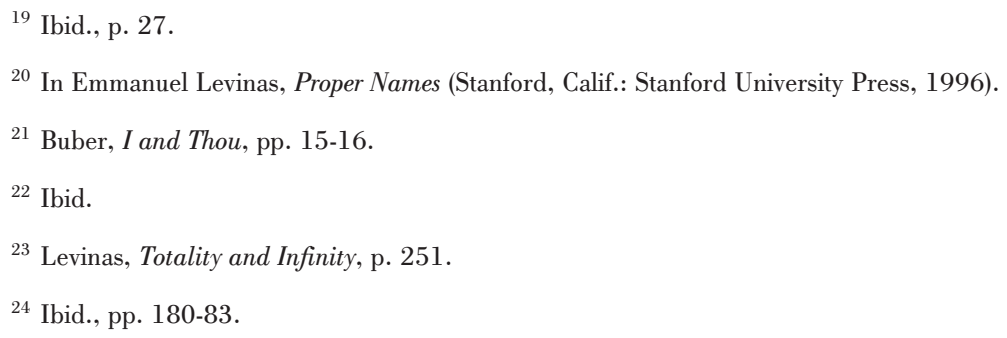


would find in a world entirely bound by "I - It" relations. Basing our being in "I - Thou" relations urges us to forge a culture of community lived toward the Other, placing the Other before ourselves and accepting the responsibility for maintaining this relationship. But here we must pause.

It would be quite easy to assume that this model could only be maintained from a position of power, from a vantage point which can impose the proper observance of the principle to be strived toward. This is far from the state of affairs envisioned by Buber, however. Indeed, Buber recognizes in the prophetic tradition the theme which necessitates that this message be propounded from a position of powerlessness. Prophets cannot impose their lessons. ${ }^{25}$ The lessons must be heard on their own, and accepted by those the prophet engages. The call is made, but the struggle must take place individuallyin each of us-to place ourselves into these sorts of relations.

It warrants saying here that this alternative paradigm does not hope to eradicate conflict or dissent. In fact, it is very often the case in Buber's writings that he discusses the issue of conflict, confrontation and opposition. It is how we react to such confrontation and dissent that concerns him most, for to maintain the proper relationship with the Thou we must account and allow for disagreement and even conflict. We cannot, however, respond in any way which diminishes the pure alterity or exteriority of the Thou. In short, we cannot attempt to impress our perspective or position on the Thou in a way which would displace or demean the alterity of its position, or engage in this conflict such that we are humiliating or subjugating the Thou.

We must return now to the idea that this alternative paradigm is founded on a distinctly privileged notion of ethics. For it is this notion which ties the privileging of powerlessness and the advancement of the Other over our interests into the redemption envisioned by advocates of the prophetic inclination. When we are faced with the Other, often in situations of strife, confrontation or conflict, we must not strike out or seek to conquer that which we are engaged with. The only possible way in which to transcend the mere existence as functional entities, the only possible path to redeem ourselves from lapsing into such existence, is to shun the impulse to defeat and subjugate the Other; to deny the disposition to use violent means to assert our self against the Other. In this tradition, facing conflict necessitates that we begin from the premise that we will not employ violence.

The proper relation to the Other, says Levinas (following Buber), is one which precludes the use of violence. This is illustrated time and again in Levinas' works by his persistent references to the proscription against murder. Levinas says, for instance, that the alterity of the Other "is manifested in the absolute resistence which by its apparition,

${ }^{25}$ Martin Buber, "Plato and Isaiah" in The Writings of Martin Buber (Cleveland, Ohio: The World Publishing Co., 1965), p. 235. 
its epiphany, it opposes to all my powers. Its epiphany is not simply the apparition of a form in the light, sensible or intelligible, but already this no cast to powers; its logo is: "you shall not kill."” ${ }_{26}$ The ethical logos behind the alternative epistemology advanced by Buber and Levinas, then, is one of nonviolence.

While this treatment scarcely scratches the surface of the complexity and sophistication with which Buber, Levinas and others in the prophetic tradition deal with the notions of alterity, Otherness, and the development of a distinctly alternative ontology, for our purposes here it is enough to try and bring to the surface the themes discussed above. The prophetic inclination seeks to foster a dialogic relationship between beings which maintains the exteriority of the Other (the Thou,) opens up the self to this Other in a way which allows for the transcendence of merely functional or instrumental associations, brings for the possibility for the revelation of true being, and precludes the use of violence in the encounter. Such goals seem, at first blush, to be perhaps too farreaching and grandiose. How likely is it that one might actually integrate this inclination into a life which is necessarily lived in a culture which militates against each of these messages at every turn? While we may be inclined to think that such an existence is not possible, I am convinced that it is indeed possible. The legacy of Martin Luther King, Jr. explicitly shows us that the application of the prophetic inclination is possible, as he integrated these themes into his social and political philosophy with relative success. In fact, the struggle for civil rights for African Americans in the United States probably would not have been possible without the influence and philosophical commitments of King; commitments that are intimately related to the prophetic inclination as developed by Buber and Levinas.

\section{KING AND THE PROPHETIC}

Early in King's academic career he was exposed to a variety of alternative voices, perspectives which opened up possibilities on the margins of Western philosophy and culture. By the time he reached the dissertation stage for his doctoral degree at Boston University, King had integrated this cacophony of voices into a coherent philosophical position which looks remarkably like the prophetic inclination I discussed above. Indeed, the questions of being and fundamental ontology serve as the main focus for much of King's thesis. Even at this early stage, then, King exhibited an orientation toward a conception of true being which finds its expression in the ability to transcend the merely

${ }^{26}$ Emmanuel Levinas, "Philosophy and the Idea of the Infinite" in To the Other: An Introduction of the Philosophy of Emmanuel Levinas, ed. Adriaan Peperzak (West Lafayette, Ind.: Purdue University Press, 2005), p. 109. 
instrumental; ${ }^{27}$ an idea which would later serve as the basis for his conception of the beloved community. ${ }^{28}$ While King would allow for this conception of community to entail interactions beyond the one to one (face to face) interactions discussed by Buber and Levinas he uses language reminiscent of Buber's formulation, often referring to Buber's "I - It" and "I - Thou" categories explicitly. ${ }^{29}$

The influence of the prophetic upon King's thought is often not quite so patent, however; a fact which might account for the seemingly absolute lack of connection between King's work and that of those in the prophetic tradition by scholars who hail each legacy independently. Later in his career, while engaged in the fight to end racial segregation in the United States, King continually brought forth the themes I have attributed to the prophetic inclination without explicitly attributing the influence of that tradition. ${ }^{30}$ Those who maintain any familiarity with King's work during the civil rights movement will surely recognize the importance which he placed on the notions of illuminating silenced voices, providing hospitality to the one who is engaged in your degradation, and the need to address and confront that Other directly and honestly. ${ }^{31}$

Arguably, these ideas serve as the framework for King's social and political theory. For only through the execution of these ideas can the struggle for redemption and social justice take place. Again, like Buber and Levinas, King maintained that this struggle is a personal one which must be purposefully engaged in independently by those who hear the call. Indeed, engaging in such struggle is the only true way in which one can affect the Other and maintain the integrity of an "I - Thou" relationship. The implication being that the terms of such a relationship will allow the Other to see your humanity through your struggle and sacrifice. The key is to affect the Other without the use of humiliation or subjugation, to start from a vantage point which privileges ethics. The recognition of

${ }^{27}$ It should be noted here that King's thesis squarely concerns a religious rather than a philosophical question. Nonetheless, he employs philosophical conceptions clearly related to the prophetic inclination developed by Buber and Levinas with great adeptness. While there is a distinctly religious edge to the work of all three of these men, I believe that the themes I have identified are more properly philosophical. While I do not mean to imply that the religious thought of Buber, King and Levinas had no effect upon their work in general, I would maintain that the ideas discussed in this paper are not, in the main, religious notions.

${ }^{28}$ King confronted the mere functionality of what he called crass relationships in several places. See, e.g., Martin Luther King, Jr. Strength to Love (New York: Harper and Row, 1963).

${ }^{29}$ See, e.g. Martin Luther King, Jr. Why we Can't Wait (New York: Harper and Row, 1964), pp. 87-88.

${ }^{30}$ Interestingly, others have made the connection between the struggle for civil rights in the U.S. and the prophetic tradition. See, for example, William Rogers, We are All Together Now: Frederick Douglass, William Lloyd Garrison, and the Prophetic Tradition (New York: Routledge, 1995).

${ }^{31}$ Like Buber, King frequently employed the use of parable to get these ideas across (often using the same parables used by Buber). This method is used extensively in King's book Strength to Love (New York: Harper \& Row, 1963). 
the innate dignity and worth of each individual's humanity leaves us with the necessity of affecting the Other by implication and example. ${ }^{32}$ This leads to the possibility that both parties will have the possibility of redemption open to them. ${ }^{33}$

Finally, the theme of nonviolence which I drew out of the prophetic tradition comes to full fruition in King's work. It is, perhaps, what King is most widely known for. Like Levinas, the engagement of one with the Other in a way which allows for conflict, confrontation and dissent without allowing for the possibility of the use of violent means in the course of such interaction was the fundamental premise from which King began his social philosophy. ${ }^{34}$ Only through the explicit adoption of non-violence can we maintain the "I - Thou" relationship with one who is oppressing us. King says, for example, that "[t]hrough nonviolent resistance we shall be able to oppose the unjust system and at the same time love the perpetrators of the system." 35

As an organizer, King was a master of marshaling the moral elements at work in any conflict to illuminate both the positions of oppressed African Americans as well as the white majority that was oppressing them. For example, in his famous "I have a Dream" speech in Washington, D.C., king said:

But there is something that I must say to my people who stand on the warm threshold which leads into the palace of justice. In the process of gaining our rightful place we must not be guilty of wrongful deeds. Let us not seek to satisfy our thirst for freedom by drinking from the cup of bitterness and hatred.

We must forever conduct our struggle on the high plane of dignity and discipline. We must not allow our creative protest to degenerate into physical violence. Again and again we must rise to the majestic heights of meeting physical force with soul force. The marvelous new militancy which has engulfed the Negro community must not lead us to distrust of all white people, for many of our white brothers, as evidenced by their presence here today, have come to realize that their destiny is tied up with our destiny and their freedom is inextricably bound to our freedom. We cannot walk alone. ${ }^{36}$

Here we see King's dedication to several principles. First, he implores oppressed blacks to accept the principle of nonviolent action. Secondly, he explicitly posits this adherence to an ethical relationship with the Other that requires, indeed compels, oppressed blacks to acknowledge and respect the alterity of the Other. Finally, King maintains that this acknowledgement and respect is necessary because the relationship

${ }^{32}$ See supra note 14 .

${ }^{33}$ King explicitly says this in his essay "Pilgrimage to Nonviolence" in Staughton Lynd, Nonviolence in America (Indianapolis, Ind.: Bobbs Merrill Co., 1966), p. 392

\footnotetext{
${ }^{34}$ See supra notes $29 \& 33$.

${ }^{35}$ King, Strength to Love, p. 6.

36 The full text of this speech can be found online at: http://www.mlkonline.net/dream.htm.
} 
with the Other is reciprocal. This is to say, according to King-like Buber and Levinasour lived relationship with the Other says as much about us as it says about the Other. In turn, the Other is inextricably bound with us in their own lived experience.

King believed, and I am convinced he derived this in substantial part from the work of those in the prophetic tradition like Buber, that we can pull the Other into a higher moral plane by our own actions in the face of the Other. This is more than a commitment to nonviolence, it is a dedication to try and raise the moral and ethical status of the conflict with the Other by being as concerned with the Other's wellbeing as we are with our own. This is something that set King apart in the American civil right movement. At a time when so many in the movement were critiquing the white majority for their oppressive history and resistance to change, and often even explicitly calling for violent action against segregationists, King was reminding oppressed African Americans and white segregationists that we rise up out of the destructive dynamic of racism together, or we remain mired in that degradation together. What could be a better characterization for the relationship between I and Thou?

While there are indeed many unexplored connections between the alternative epistemological paradigm developed in the prophetic tradition and the work of Martin Luther King, Jr. it is not the case that King's thought is a mere recapitulation of ideas put forth by Buber, Levinas and others. King clearly attempted to draw from these ideas, indeed I believe that they have had a much greater impact than anyone has recognized to date, but he did not stop there. He attempted to push beyond the conceptualizations as originally posited and apply them in contexts which stretched past the conceptual limitations imposed by those in the prophetic tradition to encompass the social and intellectual realities as he saw them through the lens of American segregation and racism.

He was clearly successful at some level, for the legacy of King's work today is the novelty with which he addressed the problems of his day. I accept this appraisal, but wish to add to it the realization that there is a tradition-a philosophical tradition-which has endorsed and embraced the concepts which King employed so adeptly during the U.S. civil rights movement. Indeed, in many ways this tradition was an important progenitor to King's views. The notions of redemption, transcendence and nonviolence have had, and continue to have, a tremendous effect on an inclination which seeks to circumvent the traditional Western move to appropriate and conquer the Other and make it same. This prophetic inclination offers a real opportunity to think about our confrontations with others in a decidedly unique and perhaps more constructive way, an opportunity which I am convinced King saw clearly and capitalized upon to a degree remarkable in his or any time. In this sense, then, it is not untoward to say that King was indeed an American Prophet. 


\section{BIBLIOGRAPHY}

BALDWIN, Lewis V. There is a Balm in Gilead: The Cultural Roots of Martin Luther King, Jr. (Minneapolis, Minn.: Augsburg Fortress, 1991).

BENNETT, Scott H. Radical Pacifism: The War Resisters League and Gandhian Nonviolence in America, 1915-1963. (Syracuse, N.Y.: Syracuse University Press, 2003).

BERGO, Bettina. "Is There a "Correlation" Between Rosenzweig and Levinas?" The Jewish Quarterly Review, Vol. 96 (Summer 2006), p. 404.

BRUEGGMANN, Walter. The Prophetic Imagination (Minneapolis, Minn.: Fortress Press, 2001).

MARTIN, Buber. The Prophetic Faith (New York: Collier Books, 1985).

MARTIN, Buber. "Plato and Isaiah" in The Writings of Martin Buber (Cleveland, Ohio: The World Publishing Co., 1965), p. 235.

MARTIN, Buber. I and Thou (New York: Collier Books, 1958).

COLAIACO, James A. Martin Luther King, Jr.: Apostle of Militant Nonviolence (London: MacMillan Press, 1988).

FLOYD, Timothy W. "Lawyers and Prophetic Justice," Mercer Law Review, Vol. 58 (2007), p. 513.

GANDHI, M.K. Gandhi on Nonviolence: A Selection from the Writings of Mahatma Gandhi (New York: New Directions Press, 1965).

GARROW, David. Bearing the Cross: Martin Luther King, Jr. and the Southern Christian Leadership Conference (New York: Harper, 2004).

KING, Martin Luther Jr. The Collected Papers of Martin Luther King, Jr.: Vol. II (Berkeley: University of California Press, 1994).

KING, Martin Luther Jr. Why we Can't Wait (New York: Harper and Row, 1964).

KING, Martin Luther Jr. Strength to Love (New York: Harper and Row, 1963).

LEVINAS, Emmanuel. Proper Names (Stanford, Calif.: Stanford University Press, 1996).

LEVINAS, Emmanuel. Totality and Infinity: An Essay on Exteriority (Pittsburgh, Pa: Duquesne University Press, 1961).

LEVINAS, Emmanuel. To the Other: An Introduction of the Philosophy of Emmanuel Levinas, ed. Adriaan Peperzak (West Lafayette, Ind.: Purdue University Press, 2005).

LYND, Staughton. Nonviolence in America (Indianapolis, Ind.: Bobbs Merrill Co., 1966).

ROGERS, William. We are All Together Now: Frederick Douglass, William Lloyd Garrison, and the Prophetic Tradition (New York: Routledge, 1995).

ROSENZWEIG, Franz. The Star of Redemption (Madison, Wisc.: University of Wisconsin Press, 2005).

STEINKRAUS, Warren. Studies in Personalism: Edgar Sheffield Brightman (Meridian, Miss.: Meridian Pub., 1984).

WALTON, Hanes Jr. The Political Philosophy of Martin Luther King, Jr. (Westport, Conn.: Greenwood Publishing Co., 1971).

WEST, Cornel. The American Evasion of Philosophy: A Genealogy of Pragmatism (Madison, Wisc.: University of Wisconsin Press, 1989). 